\title{
KECEPATAN GELOMBANG GESER (VS) DAN KETEBALAN SEDIMEN (H) DI KABUPATEN KLATEN DARI DATA MIKROTREMOR
}

\author{
Anggit Mas Arifudin ${ }^{1, *}$ \\ ${ }^{1, *)}$ Jurusan Teknik Sipil, Fakultas Teknik Sipil dan Perencanaan, Universitas Islam Indonesia \\ Email: anggit.mas@uii.ac.id
}

\begin{abstract}
Research on Shear Wave Velocity (vs) and Sediment Thickness ( $h$ ) in Klaten Regency, Central Java from field microtremor data aims to determine the thickness of sediment or soft sediment as one factor of high and low earthquake vulnerability. Microtremor data was collected using a three-component TDS 303 seismometer covering 111 measuring points in the Klaten Regency area. In this study, the sediment thickness was calculated using the equation shear wave velocity $(v s)$ divided by four times the dominant frequency $(f g)$. The dominant frequency $(f g)$ value is obtained from the HVSR curve. In contrast, the shear wave velocity value (vs) used in this study is the inversion value of the HVSR curve, which is modeled based on borlog data at the Wedi Church, equated for all measurement points. The map of the shear wave velocity distribution at each microtremor measuring point has a vs value; this value is used to calculate the thickness of the sediment at each end. So that the distribution of the thickness value of the sediment at each point is obtained, then a thickness map is made covering the study area. The results showed that, in general, the research area has a Vs value in the effects of the HVSR curve inversion ranging from $130 \mathrm{~m} / \mathrm{s}$ to $570.83 \mathrm{~m} / \mathrm{s}$, Vs average $275.68 \mathrm{~m} / \mathrm{s}$. The areas with $v$ s are relatively high in the southern part of Gantiwarno, Wedi, and Bayat subdistricts directly adjacent to Gunung Kidul. Areas with relatively low-value of vs are in Prambanan Subdistrict, Northern Wedi Subdistrict, Trucuk Subdistrict, Jogonalan Subdistrict, South Klaten District, Central Klaten District, and Kalikotes Subdistrict. For sediment thickness (h) ranges from 5,105 m to 113,648 m. Areas with relatively high sediment thickness are located in parts of Wedi Subdistrict with a thickness of up to $110 \mathrm{~m}$. Areas with medium thickness (around 60 to $90 \mathrm{~m}$ ) are in the Gantiwarno sub-district, Prambanan district, and the southern part of the Jogonalan sub-district. In Bayat District, it has a low thickness (about 5 to $30 \mathrm{~m}$ ) located in the proves and mountains of the Paseban area and the tomb of Sunan Pandanaran. The result shows that areas with high sediment thickness, namely in Wedi District, have a high level of earthquake vulnerability.
\end{abstract}

Keywords: shear wave velocity, sediment thickness, HVSR curve inversion, microtremor

\section{PENDAHULUAN}

Indonesia merupakan titik temu antara tiga lempeng besar dunia, yaitu Lempeng Pasifik, Lempeng Eurasia, dan Lempeng HindiaAustralia yang lazim disebut Triple Junction. Pergerakan Lempeng Hindia-Australia setiap tahunnya sekitar $7 \mathrm{~cm}$ ke arah utara, Lempeng Pasifik sekitar $11 \mathrm{~cm}$ tiap tahunnya ke arah barat daya, dan lempeng Eurasia sekitar $9 \mathrm{~cm}$ tiap tahunnya ke arah selatan. Dampak pergerakan lempeng triple junction menyebabkan kepulauan Indonesia mempunyai tingkat kegempabumian cukup tinggi sehingga rawan gempabumi tektonik.

Gempa bumi Yogyakarta mengakibatkan 5.716 orang meninggal, 126.326 tempat tinggal rusak berat, dan 1.275 infrastruktur rusak parah. Wilayah yang mengalami kerusakan terparah di Jawa Tengah adalah Kabupaten Klaten, dengan 1.041 orang meninggal, 30.300 rumah rata dengan tanah, dan 76 bangunan pemerintah rusak. Sebagian besar wilayah Klaten yang mengalami kerusakan parah yaitu Kecamatan Wedi dan Kecamatan Gantiwarno. 
Kerusakan yang terjadi akibat gempa bumi Yogyakarta ini ternyata memiliki pola persebaran yang tidak merata, tidak teratur, dan blok-blok wilayah tertentu. Kondisi geologi dan jenis tanah memegang peranan penting dalam menimbulkan tingkat kerusakan. Daerah yang dekat dengan sumber gempa tidak semuanya rusak parah sedangkan yang jauh dari pusat gempa tidak aman secara keseluruhan. Lapisan tanah lunak dan tebal lapisan tanah yang berada di atas batuan dasar bisa meningkatkan faktor amplifikasi gelombang gempa bumi dan efek pantulan gelombang gempa bumi dari batuan dasar. Cepat rambat gelombang juga akan sangat lambat pada lapisan lunak dibanding dengan lapisan keras.

Gempa bumi merupakan bencana yang tidak dapat diprediksi kapan, dimana dan berapa kekuatan kejadiannya. Pemerintah dan masyarakat dapat melakukan usaha mitigasi bencana dengan cara mengetahui penyebab dan zona-zona yang sangat rawan hingga zona yang relatif aman terhadap bahaya gempa bumi. Dalam penelitian ini akan dilakukan pengukuran mikrotremor yaitu getaran tanah dengan amplitudo mikrotremor yang dapat ditimbulkan oleh peristiwa alam dan aktifitas angin, gelombang laut, mesin, kendaraan, dan lain-lain. Pengukuran di beberapa titik ukur di wilayah Kabupaten Klaten bagian selatan untuk mengetahui nilai kecepatan gelombang geser dan karakteristik dinamik tanah sebagai salah satu upaya mitigasi gempa bumi. Getaran mikrotremor diukur di permukaan dilakukan dengan seismograf. Data mikrotremor selanjutnya diolah untuk memperoleh nilai faktor amplifikasi spektrum tanah (Ag), frekuensi dominan (fg), selanjutnya diolah untuk mendapatkan nilai kecepatan gelombang geser (vs) dengan inversi kurva HVSR kemudian dapat digunakan untuk menghitung ketebalan sedimen (h).

\section{Kondisi Geologi Kabupaten Klaten}

Daerah penelitian merupakan bagian dari zona kaki gunung Merapi, yang terdiri dari deposit fluviovulcanic Kuarter. Menurut peta geologi lembar Surakarta dan Giritontro (Pusat Penelitian dan Pengembangan Geologi), batuan yang menyusun wilayah Kabupaten Klaten secara umum termasuk jenis batuan berumur kuarter dan tersier. Batuan kuarter tersebut penyusunnya adalah batuan gunung api merapi (Qvm), dan batuan alvium tua $(\mathrm{Qt})$. Batuan tersier pada daerah penelitian adalah batuan formasi wonosaripunung (Tmwl), batuan malihan (KTm), batuan formasi gamping wungkal (Tew), batuan diorit pendul (Tpdi), dan batuan formasi kebobutak (Tomk).

Di Kecamatan Prambanan, Jogonalan, Klaten Selatan, Klaten Tengah, Gantiwarno, Wedi, dan Trucuk sebagian besar tersusun dari batuan gunung api merapi (Qvm). Wilayah kecamatan Bayat bagian utara yang terdapat Gunung Kebo dan Gunung Tugu tersusun dari batuan malihan (KTm), batuan diorit pendul (Tpdi), dan batuan gamping wungkal (Tew). Wilayah Kecamatan Cawas bagian barat yang terdapat Gunung Konang tersusun dari batuan malihan (KTm), batuan diorit pendul (Tpdi), dan batuan gamping wungkal (Tew). Susunan batuan formasi wonosari-punung (Tmwl) terletak di wilayah sekitar Rowo Jombor dan Jimbung. Wilayah Gedangsari Gunung Kidul yang menjadi batas selatan Kabupaten Klaten tersusun dari batuan formasi kebobutak (Tomk).

Daerah kerusakan gempa bumi umumnya terkonsentrasi pada daerah-daerah yang disusun oleh sedimen gunung api merapi yang berumur kuarter. Selain itu daerah kerusakan dapat pula dijumpai di daerah - daerah yang disusun oleh batuan holosen berupa endapan dan gosong sungai. Sungai besar yang terdapat di daerah penelitian adalah Sungai Dengkeng, yang melewati wilayah kecamatan Bayat dan Cawas. 


\section{METODOLOGI PENELITIAN}

Data survei mikrotremor diperoleh dari pengukuran yang dilakukan di titik pengukuran yang direncanakan tersebar di daerah penelitian sebanyak 111 titik. Teknik penentuan titik ukur direncanakan berupa grid meliputi daerah penelitian dengan interval \pm $1,5 \times 1,5 \mathrm{~km}$. Titik pengukuran dapat dilihat pada Gambar 1. Pengukuran dilakukan dengan menggunakan TDL 303s Digital Portable Seismograph.

Lokasi penelitian terletak di wilayah Kabupaten Klaten meliputi 9 kecamatan, yaitu : Kecamatan Gantiwarno, Wedi, Bayat,
Kalikotes, Klaten Tengah, Klaten Selatan, Jogonalan, Prambanan, Trucuk dan sebagian wilayah Kabupaten Gunung Kidul yang berbatasan dengan Kabupaten Klaten.

Perangkat lunak (software) yang digunakan dalam penelitian ini adalah DataPro, Google Earth, Sessary Geopsy, Dinver, ArcGIS, Microsoft Word 2007, dan Microsoft Excel 2007, sedangkan perangkat keras (hardware) yang digunakan adalah Global Positioning System (GPS), seismometer, digitizer tipe TDL-303S, antena GPS, kabel, kompas, UPS (Uninterruptible Power Supply), dan laptop.

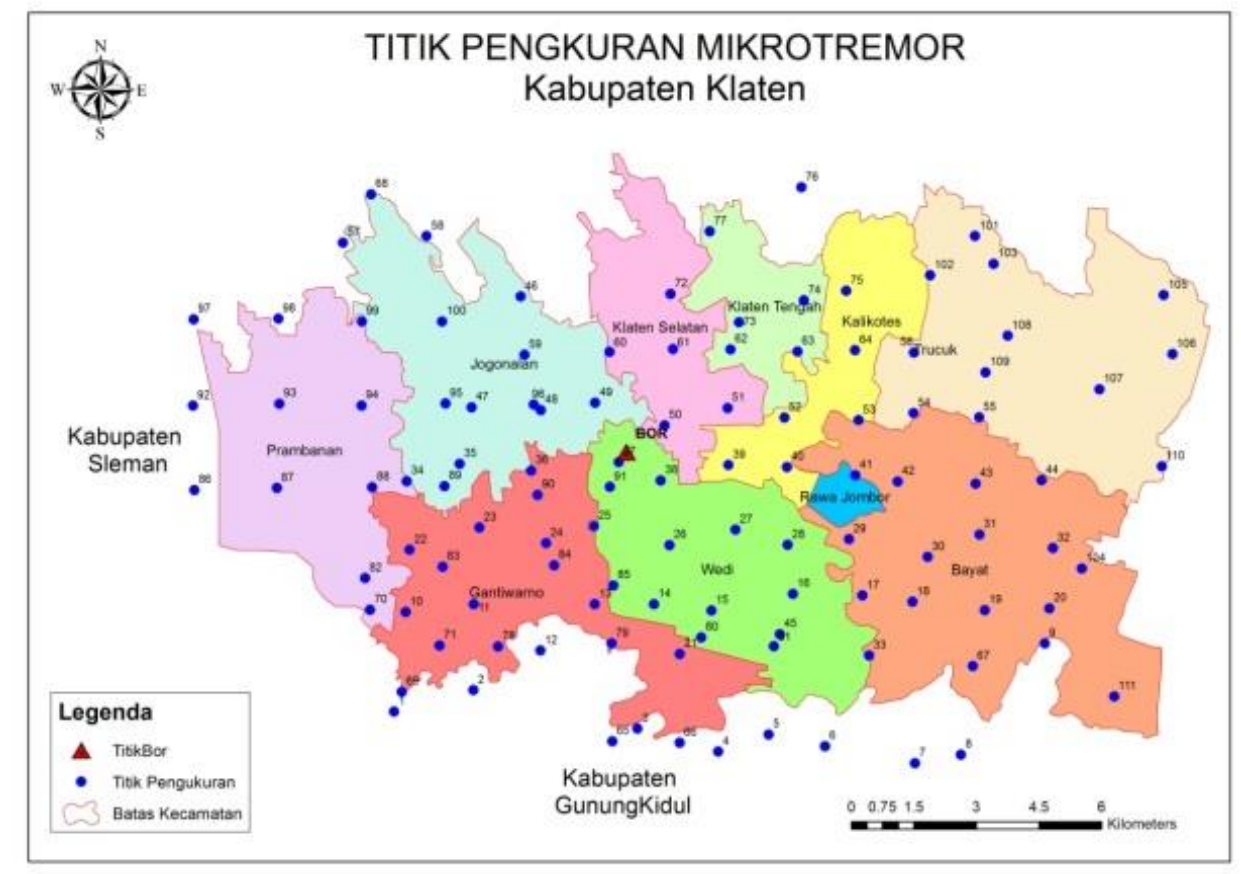

Gambar 1. Titik pengukuran mikrotremor dan bor

\section{Teknik Analisis Data}

Pengolahan data mikrotremor menggunakan metode analisis Horizontal to Vertical Spectrum Ratio (HVSR). Hasil pengukuran mikrotremor di lapangan mendapatkan data getaran tanah fungsi waktu. Data ini tercatat dalam tiga komponen, yaitu komponen vertikal (up-down), utara-selatan (northsouth), dan barat-timur (east-west). Data mentah ini tidak dapat langsung diolah karena dalam format hexadecimal. Data ini harus diubah ke format ASCII atau format miniseed (MSD) menggunakan perangkat lunak DataPro dan menghasilkan empat file, yaitu file komponen vertikal, utara-selatan, barattimur, dan file header.

Proses pengolahan data mikrotremor menggunakan perangkat lunak Geopsy untuk memperoleh rata-rata spektrum $\mathrm{H} / \mathrm{V}$ dari rekaman getaran yang datanya telah disiapkan 
sebelumnya. Perangkat lunak Geopsy ini akan memberikan grafik kurva HVSR, yang terdapat nilai frekuensi dominan $(f g)$ dan puncak kurva HVSR (faktor amplifikasi tanah, $A g$ ). Kecepatan gelombang geser $(V s)$ diperoleh dari analisis kurva $\mathrm{H} / \mathrm{V}$ menggunakan metode ellipticity curve (inversi) pada program Dinver dengan parameter tanah yang didapatkan dari data bor N-SPT di Gereja Wedi.

Sehubungan dengan keterbatasan dana penelitian maka hanya bisa dilakukan 1 titik bor N-SPT saja, untuk validasi yang lebih baik harus menggunakan referensi titik bor yang lebih banyak lagi dengan interval yang rapat. Penelitian selanjutnya akan menambah titik bor sebagai referensi untuk validasi nilai parameter tanah di wilayah Kabupaten Klaten. Hasil dari metode inversi kurva HVSR yaitu ground profiles kecepatan gelombang geser $(V s)$. Garis hitam pada ground profiles Gambar 3 , menunjukkan model dengan nilai misfit (ketidaksesuaian) yang terbaik.

Setelah kecepatan gelombang geser $(V s)$ di setiap titik penelitian diperoleh, selanjutnya ketebalan sedimen (h) bisa dihitung menggunakan Persamaan (1) di bawah ini, dari SESAME (2004).

$$
h=\frac{v_{s}}{4 f g}
$$

dengan

$h \quad$ : ketebalan sedimen

$v_{s}$ : kecepatan gelombang geser

$f g$ : frekuensi dominan

\section{HASIL DAN PEMBAHASAN}

Kecepatan Gelombang Sekunder (Vs) Inversi Kurva HVSR Mikrotremor

Kecepatan gelombang geser (shear wave) adalah paramater yang penting untuk menentukan karakteristik dinamika tanah. Gelombang S di perlukan dalam analisa dan evaluasi site effect khususnya pada lapisan sedimen yang berada diatas batuan dasar. Vs ditentukan dari perambatan gelombang seismik yang tegak lurus terhadap arah rambatan gelombangnya. Nilai kecepatan gelombang geser dapat merupakan representasi dari sifat geser struktur tanah (Ari Sungkowo, 2016).

Beberapa metode dapat digunakan untuk menghitung kecepatan gelombang geser tanah, diantranya metode geofisika dan metode geoteknik. Kecepatan gelombang geser dapat dicari dengan menggunakan beberapa teknik misalnya teknik lobang silang (cross-hole technique), downhole logging, N-SPT value dan metode survei lainnya.

Penentuan kecepatan gelombang geser (Vs) dalam penelitian ini digunakan pendekatan metode elipcity curve inversi kurva HVSR, dengan software Dinver pada Geopsy. Software ini bekerja dengan melakukan iterasi pada model awal (inisial model) untuk dicocokkan dengan kurva HVSR hasil pengukuran sampai didapatkan model akhir (final model) yang sedikit ketidaksesuaiannya (misfit) dengan kurva HVSR hasil pengukuran. Model awal metode dibuat dengan memasukkan parameter-parameter tanah yang akan ditinjau, yaitu vp, vs, poisson ratio, vs, dan density. Parameter tersebut diasumsikan sama untuk semua titik pengukuran, dikarenakan terbatasnya data tentang properties tanah di lokasi penelitain. Dalam pemodelan ground profile diambil acuan dari data sekunder borlog di Gereja Wedi, dengan kedalaman $20 \mathrm{~m}$ dan terdiri dari 6 lapisan tanah. Sebagai contoh tampilan software Dinver dapat dilihat pada Gambar 2, sebagai hasil dari inversi kurva HVSR pada titik 10 dapat dilihat pada Gambar 3, dengan garis hitam merupakan model terbaik dengan misfit terkecil. 


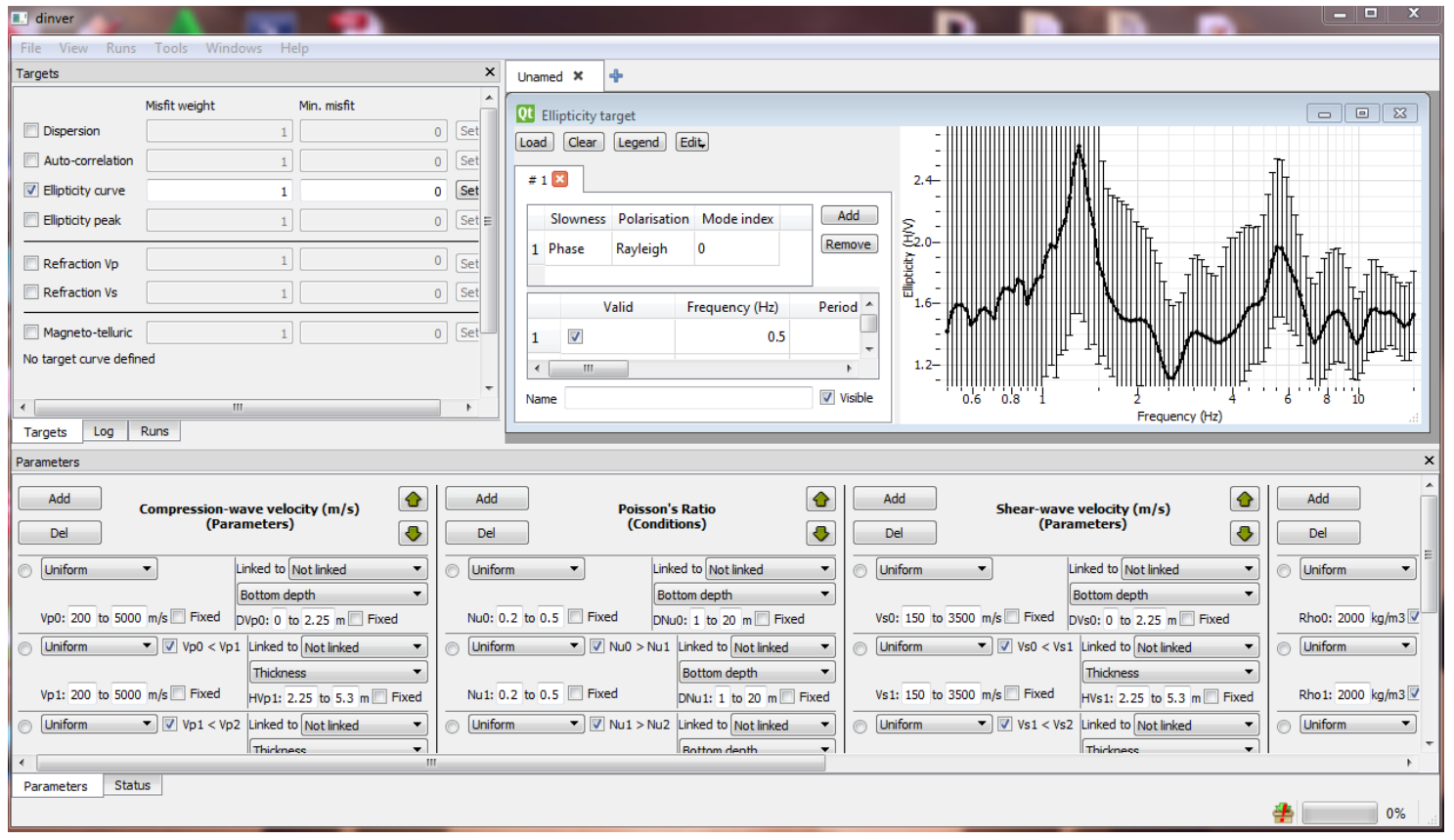

Gambar 2. Tampilan inversi kurva HVSR software Dinver

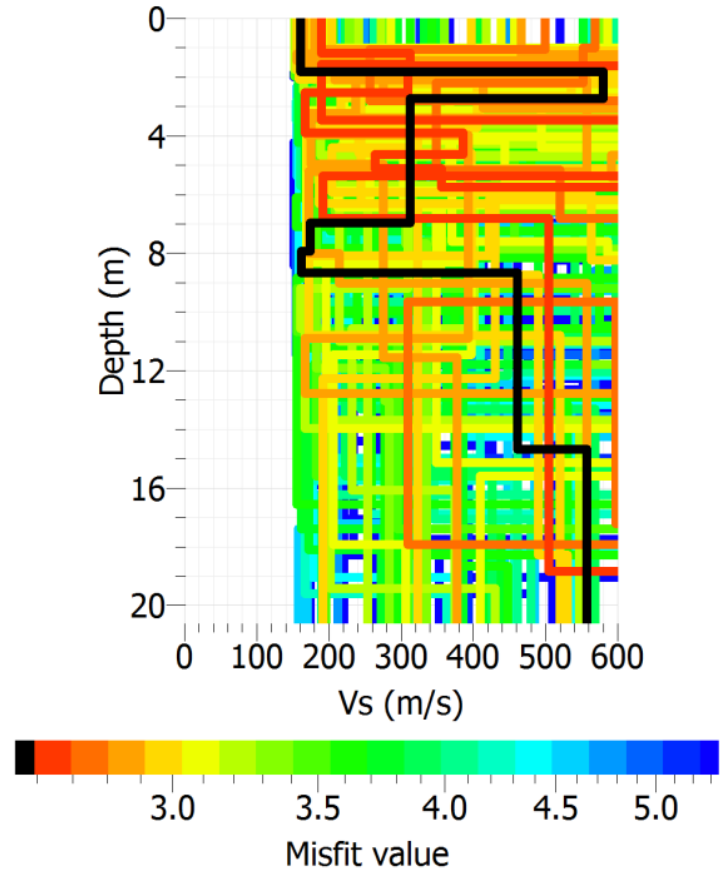

Gambar 3. Hasil akhir ground profile titik 10

Pada Gambar 3 di atas didapatkan nilai Vs setiap lapisan, ketebalan setiap lapisan, dan nilai Vs rata-rata, seperti ditunjukkan pada Tabel 1 di bawah ini. 
Tabel 1. Rekapitulasi nilai $v_{s}$ titik 10

\begin{tabular}{|c|c|}
\hline $\begin{array}{c}\text { Tebal } \\
\text { Lapisan }(\mathrm{m})\end{array}$ & $v_{s}(\mathrm{~m} / \mathrm{s})$ \\
\hline 1,8 & 160 \\
\hline 1 & 540 \\
\hline 4,2 & 280 \\
\hline 0,6 & 160 \\
\hline 1,4 & 150 \\
\hline 21 & 450 \\
\hline
\end{tabular}

Kemudian dihitung nilai $V s$ sampai kedalaman $30 \mathrm{~m}\left(v_{s} 30\right)$ pada titik 10, dengan persamaan dari SNI 1726-2019:

$$
\begin{aligned}
V_{s 30} & =\frac{h 30}{\sum \frac{h i}{v s i}} \\
& =\frac{30}{\frac{1,8}{160}+\frac{1}{540}+\frac{4,2}{280}+\frac{0,6}{160}+\frac{1,4}{150}+\frac{21}{450}} \\
& =299,6053 \mathrm{~m} / \mathrm{s}
\end{aligned}
$$

Variasi kecepatan gelombang geser utamanya tergantung dari keras lunaknya lapisan tanah. Nilai $V s$ di daerah penelitian dari hasil inversi kurva HVSR berkisar antara $130 \mathrm{~m} / \mathrm{s}$ sampai dengan $570,83 \mathrm{~m} / \mathrm{s}, v_{s}$ rata-rata $275,68 \mathrm{~m} / \mathrm{s}$ sebagaimana dapat dilihat pada Gambar 4 Dari nilai $v_{s}$ berdasarkan SNI 1726-2019 tentang Perencanaan Bangunan Tahan Gempa dapat diklasifikasikan jenis tanah pada daerah penelitian. Peta Persebaran Jenis Tanah Kabupaten Klaten dapat dilihat pada Gambar
5. Daerah dengan $v_{s}$ relatif tinggi berada di bagian selatan Kecamatan Gantiwarno, Kecamatan Wedi, dan Kecamatan Bayat yang berbatasan langsung dengan perbukitan Gunung Kidul. Wilayah dengan $v_{s}$ bernilai relatif rendah berada di wilayah Kecamatan Prambanan, Kecamatan Wedi bagian utara, Kecamatan Trucuk, Kecamatan Jogonalan, Kecamatan Klaten Selatan, Kecamatan Klaten Tengah, dan Kecamatan Kalikotes. 


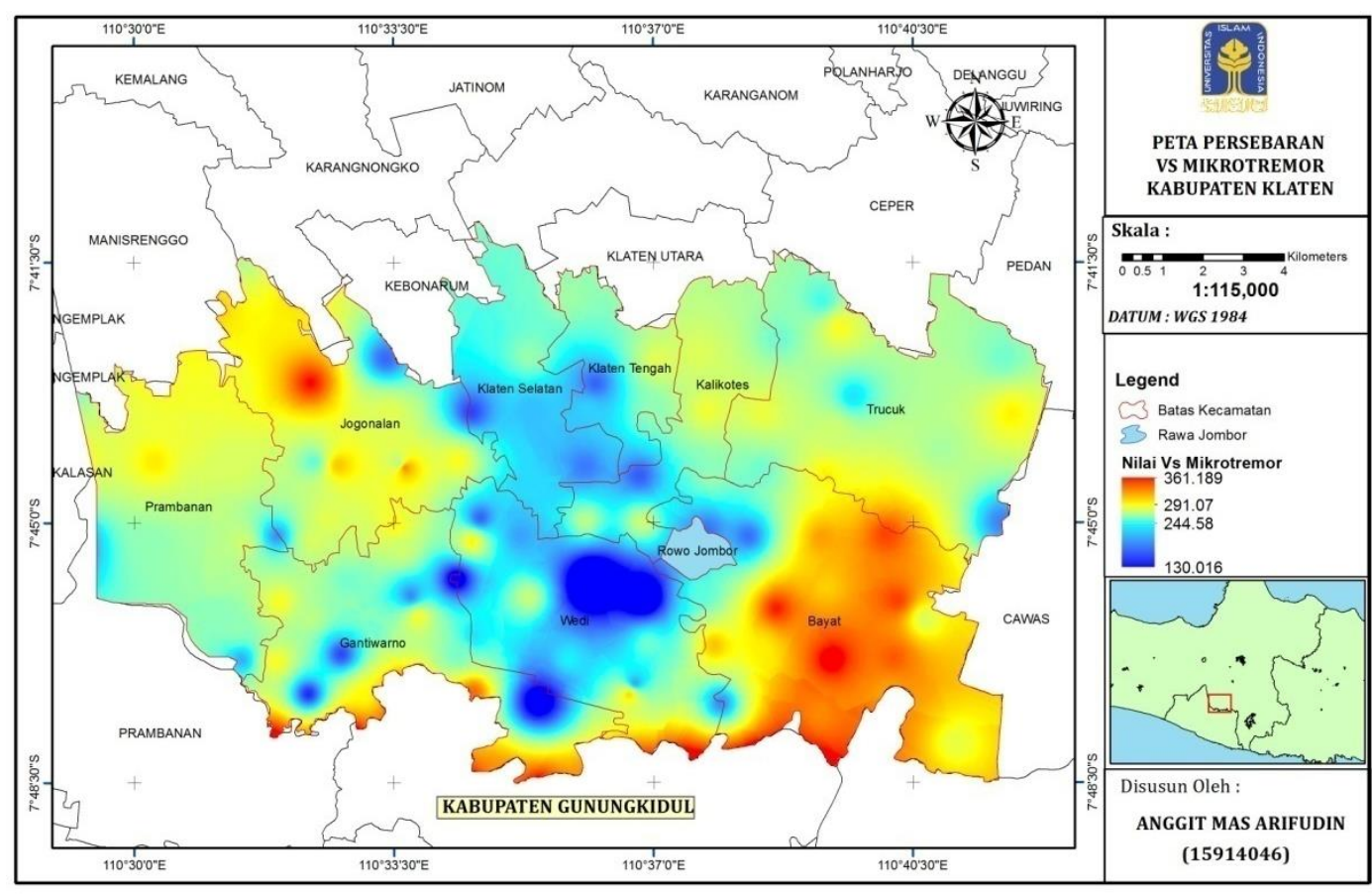

Gambar 4. Peta sebaran nilai Vs mikrotremor

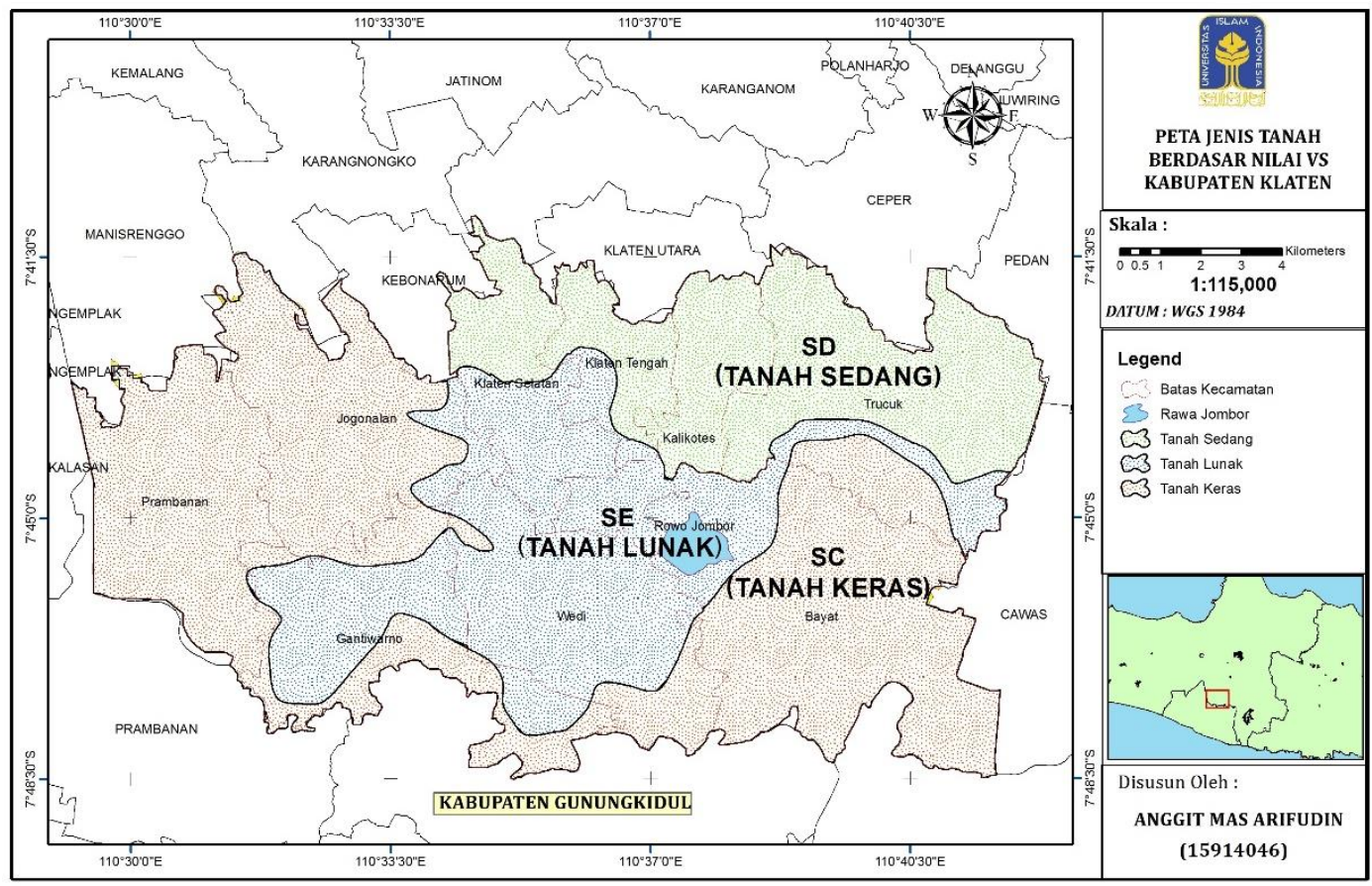

Gambar 0. Peta jenis tanah berdasarkan nilai Vs 


\section{Ketebalan Sedimen (h)}

Ketebalan sedimen dihitung dengan menggunakan rumusan seperti dalam Persamaan (1). Frekuensi dominan (fg) didapatkan dari pemodelan kurva HVSR dengan Geopsy. Dicontohkan perhitungan ketebalan sedimen (h) pada titik 10 di bawah ini.

$$
\begin{aligned}
h & =\frac{v_{s}}{4 f g} \\
& =\frac{299,6053}{4 \times 0,864554} \\
& =86,6358 \mathrm{~m}
\end{aligned}
$$

Selain frekuensi dominan, kecepatan gelombang sekunder juga menentukan hasil perhitungan ketebalan sedimen. Ketebalan sedimen dalam penelitian ini dihitung dengan menggunakan kecepatan gelombang sekunder dari hasil inversi kurva HVSR, yang dimodelkan berdasarkan data borlog di Gereja Wedi, disamakan untuk semua titik pengukuran. Secara umum daerah penelitian mempunyai ketebalan berkisar antara 5,105 m sampai dengan 113,648 m, ditunjukkan pada Gambar 6. Daerah dengan ketebalan relatif tinggi berada di sebagian wilayah Kecamatan Wedi dengan ketebalan mencapai $110 \mathrm{~m}$. Daerah dengan ketebalan sedang (sekitar 60 sampai dengan $90 \mathrm{~m}$ ) berada di wilayah Kecamatan Gantiwarno, Kecamatan Prambanan, dan bagian selatan Kecamatan Jogonalan. Di wilayah Kecamatan Bayat memiliki ketebalan rendah (sekitar 5 sampai dengan $30 \mathrm{~m}$ ) terletak di perbuktian dan pegunungan daerah Paseban dan makam Sunan Pandanaran.

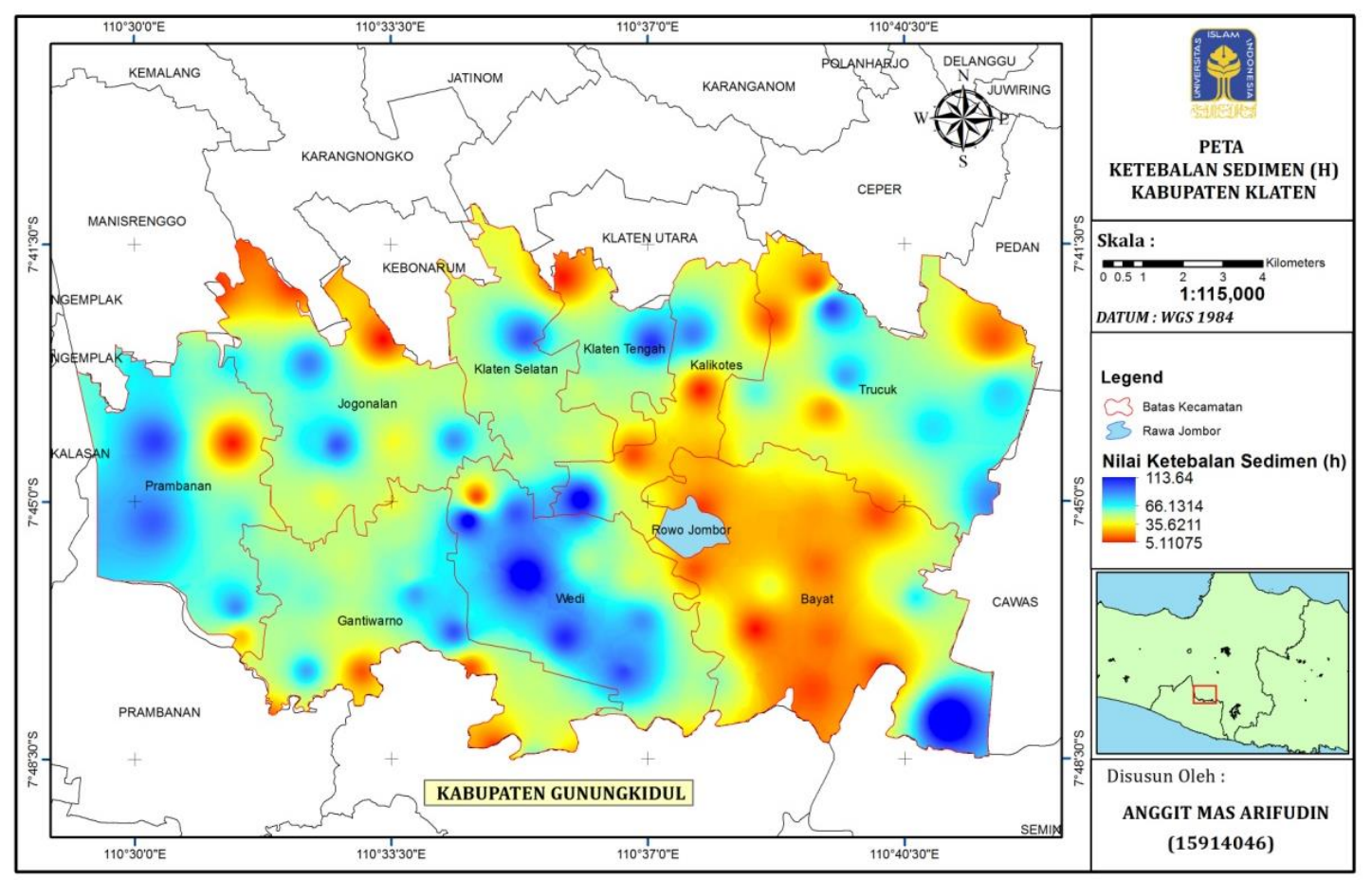

Gambar 6. Peta ketebalan sedimen (H) 


\section{KESIMPULAN}

Berdasarkan hasil dan pembahasan pada penelitian ini dapat disimpulkan bahwa karakteristik dinamik tanah ditujukkan oleh nilai kecepatan gelombang geser $v_{s}$ dengan nilai $130-570,83 \mathrm{~m} / \mathrm{s}$. $v_{s}$ bernilai rendah berada di bagian selatan Kabupaten Klaten, dan bernilai tinggi di bagian perbuktian perbatasan dengan Kabupaten Gunungkidul. Ketebalan sedimen (h) berkisar antara 5,105 $\mathrm{m}$ sampai dengan 113,648 m. Daerah dengan ketebalan relatif tinggi berada di sebagian wilayah Kecamatan Wedi dengan ketebalan mencapai $110 \mathrm{~m}$. Daerah dengan ketebalan sedang (sekitar 60 sampai dengan $90 \mathrm{~m}$ ) berada di wilayah Kecamatan Gantiwarno, Kecamatan Prambanan, dan bagian selatan Kecamatan Jogonalan. Di wilayah Kecamatan Bayat memiliki ketebalan rendah (sekitar 5 sampai dengan $30 \mathrm{~m}$ ) terletak di perbuktian dan pegunungan daerah Paseban dan makam Sunan Pandanaran. Hal ini menunjukkan daerah dengan ketebalan sedimen tinggi yaitu di Kecamatan Wedi akan memiliki tingkat kerentanan gempa yang tinggi juga.

\section{DAFTAR PUSTAKA}

Bardet, \& Tobita. (2001). "A computer program for nonlinear earthquake site response analysis of layered soil deposits". California: Department of Civil Engineering, University Of Southern California.

BMKG (2016). "Data Gempabumi dirasakan di DIY dan sekitarnya". Yogyakarta.

Daryono. (2011). "Indeks Kerentanan Seismik Berdasarkan Mikrotremor pada setiap satuan bentuk Lahan di Zona Graben Bantul Daerah Istimewa Yogkarta". Yogyakarta: Disertasi, Universitas Gadjah Mada.

Daryono, \& T. R. (2007). "Data Mikrotremor dan Pemanfaatannya Untuk Pengkajian Bahaya Gempa Bumi". Badan Meteorologu Klimatologi dan Geofisika.
Gurler, Nakamura, Saita, \& Sato. (t.thn.). "Local Site Effect of Mexico City Based on Microtremor Measurement". System and Data Research Co., Ltd, Tokyo 186-0003, Japan .

Irjan dan Bukhori, A. (2010). "Pemetaan Wilayah Rawan Bencana berdasarkan Data Mikroseismik Menggunakan TDS (Time Digital Seismograf) Type 303 Study Kasus : Kampus I UIN Maulana Malik Ibrahim Malang". Jurnal Neutrino Vol.3 No.2.

Ishihara, K. (1982). "Evaluation of Soil Properties for use in Earthquake response analysis". Proceedings International Symo. On Num. Model in Geomechanics, (hal. 237-259).

Ishihara, K. (1978). "Introduction to Dynamic Soil Mechanism. in Japanese".

Nakamura, Y. (1989). "A method for dynamic characteristic estimation of subsurface using microtremor on the ground surface". Q.R of R.T.I 30-1, 25-33.

Nakamura, Y. (2007). "Development of vulnerability assesment for ground and structures using microtremor". System and Data Research Co., Ltd .

Nakamura, Y. (2008). "On The H/V Spectrum". The 14th World Conference on Earthquake Engineering, October 12-17, 2008. Beijing, China.

SESAME. (2004). "Guidelines for the Implementation of the H/V Spectral Ratio Technique on Ambient Vibratio Measurement, Processing and Interpretation". European Commission - Reseacrh General Directorate.

Widodo. (2012). "Seismologi Teknik dan Rekayasa Kegempaan". Yogyakarta: Pustaka Pelajar. 